\title{
One hundred years later, resurrection of Tydemania gardineri A. Gepp \& E. Gepp (Udoteaceae, Chlorophyta) based on molecular and morphological data
}

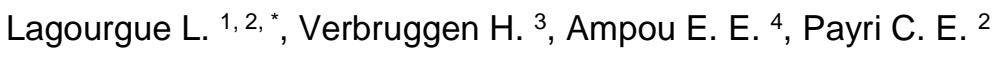

1 UPMC Univ Paris 06, Sorbonne Univ, IFD, 4 PI Jussieu, F-75252 Paris 05, France.

2 CNRS, UMR ENTROPIE, UR, IRD, BP A5 Noumea, F-98848 New Caledonia, France.

3 Univ Melbourne, Sch BioSci, Parkville, Vic 3010, Australia.

4 SEACORM INDESO Ctr, Inst Marine Res \& Observat, JI Baru Perancak, Negara Jembrana 82251, Bali, Indonesia.

*Corresponding author : L. Lagourgue, email address : laura.lagourgue@ird.fr

\begin{abstract}
:
Tydemania

Weber-van Bosse is a genus belonging to the family Udoteaceae (Bryopsidales, Chlorophyta) and currently thought to be monospecific throughout its distribution range in the Indo-Pacific. We tested the assumption that Tydemania is a single species using species delimitation methods, morphological observations and phylogenetic reconstructions of large datasets. Our molecular and morphological data recovered two distinct groups, which we argue are the type species T. expeditionis Weber-van Bosse and T. gardineri A. Gepp \& E. Gepp. The latter is currently considered a synonym of the former and we resurrect this name from synonymy. T. gardineri is distinguished morphologically from $T$. expeditionis by the complete absence of glomeruli, whereas T. expeditionis can have glomeruli and flabella, glomeruli alone, or flabella alone. The two species can also be distinguished by the shape and length of the stalks at the base of the flabellum, the diameter of the main axis and of the flabella siphons at the apices. In addition, they have different geographic distributions, with $T$. gardineri restricted to the Western Indian Ocean, and T. expeditionis extending from the Red Sea, throughout the Indian Ocean and into the West Pacific, including the Coral Triangle, the Philippines and Japan. From our dataset and literature search, we hypothesize that its south-western distribution limit is in northern Madagascar. Finally, we confirm the synonymization of $T$. mabahithae with $T$. expeditionis based on specimens from the type locality of the former and the lack of flabella in several other specimens of $\mathrm{T}$. expeditionis.
\end{abstract}

Keywords : Bryopsidales, Indo-Pacific, macroalgae, molecular data, morphology, phylogeny, species delimitation 


\section{INTRODUCTION}

Tydemania Weber-van Bosse is a genus of calcified siphonous green algae in the family Udoteaceae (Bryopsidales, Chlorophyta). The type species, Tydemania expeditionis Webervan Bosse, was described from various places in Indonesia (Kabala Dua (Makassar Strait), Saleh bay (Sumbawa Island), de Bril, and near Fau Island) following the Siboga expedition, a Dutch scientific campaign dedicated to zoological and hydrographic research in Indonesia, led by Max Carl Wilhem Weber in 1899-1900 (Weber-van Bosse, 1901). The species was described as composed of a cylindrical monosiphonous creeping or ascending axis, either branched or unbranched. Siphonous side branches of the axis form either fans (flabella) or dense ball-like structures (glomureli). The siphons branch out dichotomously in alternate planes to form the glomeruli, or in a single plane to form the flabella. Gepp \& Gepp (1911) described a second species, Tydemania gardineri A. Gepp \& E. Gepp, from specimens collected by the Bristish zoologist and oceanographer J. Stanley Gardiner in the central Indian Ocean (Chagos archipelago and Amirante Islands) during the Sealark expedition. Tydemania gardineri was distinguished by having only flabella and lacking glomeruli (Gepp \& Gepp, 1911). Nasr (1939) proposed a third species, Tydemania mabahithae Nasr, to accommodate specimens from the Red Sea. This species only has glomeruli and no flabella. Further studies, based on morphological observations, assumed that the presence of either flabella or glomureli alone may be explained by environmental conditions or life-stages, and that differences in siphon diameters were not significant (Gilmartin, 1966, Farghaly, 1980), and Meinesz (1981) proposed the merger of T. gardineri and T. mabahithae with T. expeditionis. This taxonomic decision was never confirmed by molecular data, but since then, all Tydemania records have been assigned to T. expeditionis (Guiry \& Guiry 2018).

The rich collection of Tydemania samples housed at the herbarium of Noumea (NOU) and at Ghent University (GENT) offered an opportunity to revisit the genus. The collection 
consists of 38 specimens, collected by the authors from 13 sites during several field expeditions in the Red Sea and the Indo-Pacific region, and are representative of the three morphologies, including specimens with either flabella or glomeruli only, and specimens with both. In addition, 42 digitalized specimens of Tydemania spp from $\mathrm{L}$ were examined to support the study with reference collections.

The goal of this study was to take advantage of this large dataset, and to evaluate the morphology-based synonymization of $T$. gardineri and $T$. mabahithae to $T$. expeditionis using DNA analyses. Our approach consisted of: 1) applying species delimitation methods to chloroplast and nuclear markers to evaluate species boundaries; 2) analysing whether and how morpho-anatomical observations align with suggested species boundaries; and 3) reconstructing a multilocus phylogeny ( $t u f \mathrm{~A}, r b c \mathrm{~L}$ and $18 \mathrm{~S}$ rDNA) to assess the relationships of the different samples within the genus Tydemania.

\section{MATERIAL AND METHODS}

\section{Specimen sampling:}

A total of 38 newly collected specimens of Tydemania were included in this study. The samples were collected by SCUBA between 2005 and 2017 from many locations in the Indian Ocean (Madagascar, Mayotte, Banc du Geyser, Tanzania), the Pacific Ocean (Indonesia (Bunaken); Papua New Guinea (Kavieng \& Madang); the Solomon Islands; Vanuatu; New Caledonia (Grande Terre and Loyalty islands); Fiji), and the Red Sea. Most specimens were photographed in situ prior to sampling, labeled and subsampled in both $95 \%$ ethanol and silica gel for later DNA analyses. Exceptions were specimens from the Solomon Islands, Vanuatu, and Fiji for which DNA extractions were done on herbarium material. Specimens were then pressed as herbarium vouchers and are currently housed at NOU and GENT. Herbarium abbreviations follow Thiers (2016). 
Molecular analyses:

DNA was extracted using a cetyltrimethylammonium bromide (CTAB; Doyle \& Doyle, 1987) based method with modifications (available on request). Sequences from three markers (chloroplast: tufA and $r b c \mathrm{~L}$; nuclear: $18 \mathrm{~S}$ rDNA) were obtained using primers previously published for the Udoteaceae family (Händeler et al., 2010; Kooistra, 2002; Lam and Zechman, 2006; Verbruggen et al., 2009) (Supplementary information, Table 1). PCR amplifications were conducted in a volume of $25 \mu$ l containing $12.5 \mu 1$ AmpliTaq Gold 360 Master Mix (Applied Biosystems), $0.75 \mu$ l dimethylsulfoxyde (DMSO), $1 \mu$ l bovine serum albumin (BSA), $1 \mu \mathrm{l}$ of each F and R primers $(10 \mu \mathrm{M}), 2.5 \mu 1$ DNA extract, and $6.25 \mu 1$ ultrapure water. Marker-specific PCR programs follow Lagourgue et al. (2018), and Sanger sequencing was carried out by Genoscreen using $20 \mu \mathrm{l}$ of PCR product (Lille, France).

Sequences were quality-trimmed and aligned with Geneious version 7.1.9

(http://www.geneious.com, Kearse et al., 2012) and the MUSCLE algorithm (Edgar, 2004) in Geneious, along with Tydemania expeditionis sequences downloaded from Genbank and sequences for three outgroups: Udotea flabellum (J. Ellis \& Solander) M. Howe, Udotea dotyi D.S. Littler \& Littler and Udotea geppiorum Yamada. All the specimens used in this study along with Genbank and BOLD accession numbers are listed in Supplementary Information (Table 2).

\section{Phylogenetic reconstructions:}

For the species delimitation analyses, gene trees were built using Maximum Likelihood (ML) in RAXML (Stamatakis, 2014). This was done through the CIPRES portal (Miller et al., 2010) using the GTR+G evolution model, the best scoring ML tree algorithm, 
and 1,000 bootstrap iterations (Stamatakis et al., 2008). Data were partitioned by codon position for the tufA and $r b c \mathrm{~L}$ datasets.

For phylogenetic reconstructions, the $t u f \mathrm{~A}, r b c \mathrm{~L}$ and $18 \mathrm{~S}$ rDNA alignments were concatenated. PartitionFinder v.1.1.0 (Lanfear, et al., 2012) was used to identify the best partitioning scheme for the dataset under the BIC criterion as follows: by gene and codon for tufA (F81; HKY; GTR) and rbcL (JC; GTR+G; JC; F81; JC; HKY), and as one partition only for the 18S rDNA (HKY+I). A Bayesian phylogenetic tree was obtained using MrBayes v.3.2. (Ronquist and Huelsenbeck, 2003) through the CIPRES portal, starting from a random tree and with 10 million generations of MCMC. The convergence of the runs and ESS values were checked with Tracer 1.5. (Rambaut and Drummond, 2007). The consensus topology and the posterior probabilities were computed after removing the first $10 \%$ generations as burn-in. The ML tree was built using RAXML (Stamatakis, 2014) through the CIPRES portal. The analysis was run on the dataset partitioned by gene and codon, under a GTR+G+I nucleotide model, 1,000 rapid bootstrap replicates and search for best-scoring ML tree algorithm (Stamatakis et al., 2008).

\section{Species delimitation:}

Species delimitation was assessed with the Automatic Barcode Gap Discovery method (ABGD, Puillandre et al., 2012), and the Poisson Tree Process method (PTP, Zhang et al., 2013). These two methods were chosen and combined for the complementarity of their underlying assumptions: ABGD is a distance-based method and attempts to identify a barcode gap between intra- and interspecific distances in the distribution of genetic distances between samples; PTP is a tree-based method and relies on the number of substitutions along branches to identify a shift between speciation and coalescence events.

ABGD was performed through the website http://wwwabi.snv.jussieu.fr/public/abgd/ abgdweb.html for each gene. The analysis was run under the simple distance method with 
default values for all parameters. PTP was run through the Exelixis Lab web server (http://sco.h-its.org/exelixis/web/software/PTP/index.html) on ML rooted gene trees, for 100,000 generations, a thinning value of 100 , and a burn in of $10 \%$.

\section{Morphological observations:}

Morpho-anatomical observations were made on herbarium material, decalcified in $\mathrm{HCl}$ solution (5\%), using a binocular (WILD M3Z, Heerbrugg Switzerland) and a light microscope (Imager.A2, Zeiss, AXIO) equipped with a Canon EOS 100D digital camera. They followed the descriptions and observations from previous studies (Gepp \& Gepp 1911, Weber-van Bosse 1901, and Meinesz 1981) and mainly focused on the external habit, the presence of glomeruli and flabella, the stalk (also called stipites by Gepp \& Gepp 1911) and flabellum shape, the type of attachment of the stalks to the main axis of either flabella or glomeruli (Fig.

1). Measurements of diameters were made for the main axis, and the stalk siphons for both flabella and glomeruli. Morphoanatomical observations and measurements are detailed in Supplementary Information (Table 3). We also made observations on the digitized herbarium specimens available online from $\mathrm{L}$.

\section{RESULTS:}

\section{Molecular results and species delimitation analyses}

Among the 38 Tydemania specimens available for molecular analysis, 35 were successfully sequenced and a total of 72 sequences were obtained, including 32 tufA sequences ( $841 \mathrm{bp}$ ), $25 \mathrm{rbcL}$ sequences (1306 bp), and 15 18S rDNA sequences (1243 bp), and an additional 4 tufA, $2 r b c \mathrm{~L}$, and one 18S rDNA sequences from Genbank were added. No sequences could be obtained from the pressed herbarium sheets from Fiji, the Solomon Islands, and Vanuatu. 
The ABGD and PTP species delimitation methods applied to the chloroplast and nuclear markers led to similar results with samples splitting into two groups (i.e., putative species) (see supplementary information: Figure 1, Data 1 and 2). The first group was composed of samples from the Red Sea (Egypt, Sudan), the Western Indian Ocean (Madagascar, the Maldives), Indonesia (Bunaken), the Philippines (Siquijor and Balicasag islands), Papua New Guinea (Madang), Japan (Kerama Islands, Okinawa) and New Caledonia. This group also included Genbank sequences of Tydemania expeditionis from Japan, Guam, Philippines, and Maldives. The second putative species included samples from Madagascar, Mayotte, Tanzania and the Banc du Geyser (EPI).

\section{Morpho-anatomical observations}

Photos of relevant morphological features are shown in Figures 2-24. The morphological traits of specimens from the first group matched the original description of the species Tydemania expeditionis (Weber-van Bosse 1901). We observed specimens with a creeping monosiphonous axis from which both glomeruli and flabella were arising (Fig. 2), while other specimens had glomeruli only (Fig. 3), or flabella only (Fig. 4). Nevertheless, common morpho-anatomical features are shared among all these specimens. In situ, thalli are from light to dark green with axes creeping over the substratum and, when present, glomeruli are successively stacked in an upright pompon-like structure (Fig. 3). When present, flabella are found below a series of glomeruli (Fig. 5), or arising alone along the main siphon. In both cases, the main siphon, ranging from 360 to $780 \mu \mathrm{m}$ in diameter (mean size $=518 \mu \mathrm{m} \pm 100$ ), becomes monoliform (i.e. with more constrictions) near the secondary structures (glomeruli or flabella) (Fig. 6). Flabella are generally large, monostromatic and composed of aligned and dichotomously divided siphons (Fig. 7). Some dichotomies are anisomorphic (Fig. 8). The constrictions above dichotomies show thickened cell walls. Both glomeruli and flabella are 
supported by short and thick stalks, with few dichotomies (Fig. 9 and 10), which are attached in whorls to the main axis (Fig. 11 and 12). Glomeruli siphons range from 240 to $460 \mu \mathrm{m}$ at the bases, and 80 to $180 \mu \mathrm{m}$ (mean size $=110 \mu \mathrm{m} \pm 22)$ at the apex. Flabella siphons range from 200 to $450 \mu \mathrm{m}$ at the base, and 60 to 130 (mean size $=79 \mu \mathrm{m} \pm 13$ ) at the margin. The main axis protrudes from the top of flabella or glomeruli, continuing the main growth axis of the plant (Fig. 13 and 14). A porous calcified sheath is present around the siphons.

The second group was characterized by specimens with only flabella arising from the main axis, while glomeruli were absent from all the specimens (Fig. 15 and 16). In situ, thalli form dense tufts or patches of numerous flabella, greenish-grey in color. The size of the main siphon ranges from 285 to $570 \mu \mathrm{m}$ (mean size $=426 \mu \mathrm{m} \pm 94)$. The flabella are supported by long stalks, with strongly marked constrictions giving a beaded necklace-like aspect (Fig. 17, 18 and 19). The stalks are highly dichotomously divided in alternating planes, leading to a dense and stacked mass of siphons at the basis of the flabella (Fig. 20, 21 and 22). Flabella can be of different sizes but generally small, monostromatic, and composed of dichotomously dividing siphons arranged in one plane (Fig. 24). Siphons show thickened cell walls at the strongly constricted areas above dichotomies as well as along the constrictions seen in the stalks (Fig. 23). The siphons of the flabella measure between 160 and $340 \mu \mathrm{m}$ at the base, and from 30 to $60 \mu \mathrm{m}$ (mean size $=44.5 \mu \mathrm{m} \pm 7$ ) at the apices. The calcified sheath of the siphons is porous. These observations correspond to the diagnosis of Tydemania gardineri A. Gepp \& E. Gepp. The digitized specimens L.3958458 housed in Leiden and collected in the Amirante Islands (Seychelles) by Coppejans et al. (2001) also matched the habit of the second group.

The siphon diameter data, acquired from a large collection of samples, highlighted that the main axis and the flabella siphons at the apices are thinner in $T$. gardineri than in $T$. expeditionis, a useful trait for diagnosis (Table 1). The general habit of the thalli is also useful for distinguishing between the two species, with the $T$. gardineri specimens lacking glomeruli 
and having numerous flabella arising from the main axis, and T. expeditionis having only a few flabella if any. Therefore, specimens of the $T$. gardineri group appear like dense tufts or patches of flabella (Fig. 15 and 16). In T. gardineri, the main axis is usually creeping along the substrate rather than growing upright as in T. expeditionis. The form and the length of stalks supporting the flabella are also distinctive, being long, monoliform (beaded aspect), and highly dichotomously divided in T. gardineri (Fig. 17, 18 and 19), and shorter, stockier, and less divided in T. expeditionis. Morphological differences are summarized in Table 1.

\section{Phylogenetic reconstruction}

The topologies of the phylogenetic trees were congruent between the markers $(t u f \mathrm{~A}, r b c \mathrm{~L}$, and $18 \mathrm{~S}$ rDNA) when analyzed individually or concatenated. The topology as well as nodes support were similar for ML and Bayesian trees, although ML tree appeared somewhat better resolved towards the terminal branches. We considered nodes with bootstrap values (bs) $>90$ and Posterior Probability $(\mathrm{PP})>0.95$ as highly supported. Both ML and BI trees show a well-supported dichotomy (bs: 100; PP: 1) separating the Tydemania specimens into two fully-supported clades (bs: 100; PP: 1) (Fig. 25). The first clade grouped sequences of specimens from the Indo-Pacific and morphologically identified as Tydemania expeditionis, along with sequences downloaded from Genbank. Within this clade, sequences for two specimens collected in New Caledonia grouped together in a fully supported subclade (bs: 99; PP: 0.98). The second clade included only samples collected from the Western Indian Ocean region and morphologically identified as $T$. gardineri. This clade was not subdivided in any meaningful way.

\section{DISCUSSION}


Molecular data and morphological observations support the resurrection of Tydemania gardineri

Both the molecular and morpho-anatomical analyses recovered two distinct groups of specimens among our Tydemania dataset. We assigned one to T. expeditionis based on its morpho-anatomical similarities to the species' original description by Weber-van Bosse (1901), and the second was considered to be Tydemania gardineri based on its morphoanatomical correspondence with the diagnosis of Gepp \&Gepp (1911), even though the species is currently recognized as a synonym of T. expeditionis (Guiry \& Guiry 2019).

The origin of the synonymy is due to Meinesz (1981) who based his proposition on previous studies (Srinivasan, 1954; Gilmartin, 1966) as well as his own observations. According to Meinesz (1981), the differences in siphon diameters between T. expeditionis and T. gardineri were not significant, and the author hypothesized that flabelliform thalli were juveniles of T. expeditionis, or restricted forms in unfavorable environmental conditions. Our study, however, does not support the conclusions of Meinesz (1981), and instead shows clear molecular and morphological evidence that $T$. gardineri is a distinct species. We also confirm the diagnostic characters (habit, aspect of stalks, and siphon diameters) described by Gepp \& Gepp (1911) to discriminate both species.

We were unable to compare our specimens with the holotypes of $T$. gardineri or $T$. expeditionis, since none were designated by Gepp \& Gepp (1911) or Weber-van Bosse (1901), and no lectotypes have been assigned since. Likewise, except for one specimen from the Amirante Islands, Seychelles (L.3958458, Coppejans et al. 2001), we have not been successful at finding other herbarium specimens previously identified as $T$. gardineri, either because there is no information about where they are housed, or because they have been merged with collections of $T$. expeditionis. Similarly, it was difficult to locate specimens of $T$. expeditionis but we have found the collection of Weber-van Bosse in L. None of these 
specimens were designated as holotype at the time of description, but Weber-van Bosse described the species from this Indonesian collection, which leads us to consider these specimens as syntypes. We also were not able to sequence type specimens, or newly collected specimens from the syntype localities of T. gardineri (Chagos Archipelagos or Amirante islands) or T. expeditionis (various localities in Indonesia) in our study, but we have examined specimens from neighboring localities including Mayotte and northern Madagascar for $T$. gardineri, and localities in Indonesia for T. expeditionis. This, combined with the clear morpho-anatomical differences described above give us confidence to conclude that our two genetic lineages correspond to T. expeditionis and T. gardineri.

The reappraisal of $T$. gardineri raises the question of the status of a third species, $T$. mabahithae Nasr, which was described by Nasr (1939) as having glomeruli only. The species was also synonymized with T. expeditionis by Meinesz (1981) based on morphological analysis of several samples collected from the type locality (Red Sea) similar to those described by Nasr. Meinesz could not confirm differences between T. mabahithae and T. expeditionis based on siphon diameters or other morpho-anatomical characters (Meinesz 1981). Our molecular analysis agrees with Meinesz (1981), as our sequences of Red Sea samples (Egypt, Sudan), all showing a strict glomeruli form, clearly fell in the T. expeditionis clade (Supplementary Information, Figure 1). Our results confirm that T. mabahithae should be considered a synonym of T. expeditionis as proposed by Meinesz (1981).

\section{Geographical distribution of Tydemania species}

Based on our data, the distribution of Tydemania gardineri appears to be restricted to the Western Indian Ocean whereas T. expeditionis is found across the Indo-Pacific region and the Red Sea (Fig. 25). From our data, it is possible that the southwestern boundary of $T$. 
expeditionis distribution be the northern coast of Madagascar, and that its easternmost distribution be Guam and Fiji. Northern Madagascar was the only locality where we found the two species in sympatry. Several records of $T$. gardineri are also reported for Taiwan (Shao 2003-2014) and New Caledonia (Farghaly 1980) but these are doubtful because the identifications were based on the presence of flabella only, which is a character that can be found in T. expeditionis. Some New Caledonian specimens of our own collections (e.g., NOU087203 and NOU087205) are similar in only having flabella, but grouped within the $T$. expeditionis clade based on DNA sequences. In the absence of DNA data, microscopic observations, which were not made in previous studies, would be needed to confidently assess identification based on siphon diameters, flabella shape and aspect of the stalk.

\section{Taxonomical treatment:}

Based on our results, we resurrect Tydemania gardineri, and provide a taxonomical description of the genus Tydemania and its two species: Tydemania expeditionis Weber-van Bosse and Tydemania gardineri A. Gepp \&E. Gepp. Despite intensive searches for specimens of Tydemania in various herbaria, no holotype was found. However, we found a large collection of Tydemania expeditionis specimens in L, including in the Weber-van Bosse Herbarium. Six of these specimens were collected during the Siboga expedition and very likely represent all or part of the specimens studied by Weber-van Bosse when writing the diagnoses of the genus and its type species T. expeditionis (L.3998896, L.3998892,

L.3998897, L.3998894, L.3998895, L.3998893). We consider these specimens as syntype collections of Tydemania expeditionis. We expected to find the collection of Gepp \& Gepp in $\mathrm{BM}$, but were not able to find any relevant specimens there. We have been unable to identify any other herbarium housing their collection and assume that their syntype of $T$. gardineri is lost. Only one specimen of T. gardineri collected by E. Coppejans from near one of the 
syntype localities was found in L (L.3958458, St. Joseph Atoll, Amirante Islands, Seychelles). We propose to designate this specimen as a neotype for $T$. gardineri. We further list reference DNA sequences of specimens of our own collection, collected near the type localities of both species. For each species, the list of specimens studied for DNA analysis and morphology is provided in Supplementary Information (Data 3)

\section{Tydemania, Weber-van Bosse, 1901}

Type species: Tydemania expeditionis Weber-van Bosse, 1901 Études sur les algues de l'Archipel Malaisien. (III). Annales du Jardin Botanique de Buitenzorg 17: 126-141, pls XVIIXIX

Morpho-anatomical description (adapted from the original description of Weber-van Bosse (1901) and new observations made here):

Calcareous thallus composed of a monosiphonous cylindrical axis, simple or ramified, bearing cylindrical branches with rhizoids below, and branches assembled in stacked glomeruli and/or arranged in flabella above. In the glomeruli structures, the siphons are repeatedly divided dichotomously in alternate planes and interwoven to form a dense pompon-like structure. In the flabella, siphons are divided dichotomously in one plane and are aligned and adhere to form a fan. The siphon diameter decreases towards the tips of both structures. Growth is horizontal, and in some cases vertical. Reproductive structures are unknown.

\section{Tydemania expeditionis Weber-van Bosse, 1901. Études sur les algues de l'Archipel} Malaisien. (III). Annales du Jardin Botanique de Buitenzorg 17: 39. 
Syntypes: L.3998896 (De Bril, Herb. Weber-van Bosse); L.3998893 (Banda rif, Herb.

Weber-van Bosse); L.3998894 (Muaras rif; Herb. Weber-van Bosse); L.3998895 (Saleyer rif, Herb. Weber-van Bosse); L.3998892, L.3998897 (unknown locality, Herb. Weber-van Bosse) [digitized specimens available from L].

Syntype localities: Kabala dua reefs (Makassar Strait); Saleh bay (Sumbawa Island); de Bril, and near Fau Island (Weber-van Bosse, 1901).

Morpho-anatomical description (adapted from the original description of Weber-van Bosse (1901) and new observations made here):

Thallus calcified, glaucous green, with upright structures. Main axis cylindrical to moniliform or septate-like near structures, 360-780 $\mu \mathrm{m}$ thick, with branches below bearing rhizoids, and branches above bearing glomeruli arranged in series and/or flabella. When both structures are present, flabella are found closer to the base than glomeruli. Glomeruli are composed of interwoven siphons divided dichotomously in alternate planes and form a sphere, or pomponlike structure. Glomeruli siphons measure $240-460 \mu \mathrm{m}$ at the base and $80-180 \mu \mathrm{m}$ at the apices. Flabella are monostromatic and composed of aligned siphons dichotomously divided in one plane, with symmetrical constrictions with thickened cell walls above dichotomies. Flabella are generally big and form loose groups of one to four. Flabella siphons taper from $200-450 \mu \mathrm{m}$ at the base to $60-130 \mu \mathrm{m}$ at the apices. Both glomeruli and flabella structures are borne on short and stocky stalks, dividing a few times, and arising in whorls from the main axis. Growth is both horizontal and vertical, with main axes both creeping and ascending, and apices protruding at the top of flabella and/or glomeruli series. 
Distribution records: Africa: Egypt (Marconi et al., 2011; this study), Tanzania* (incl. Zanzibar) (Coppejans et al., 2000), Sudan (this study). Indian Ocean Islands: Amirante Islands* (Silva et al., 1996), Andaman Islands * (Silva et al., 1996), Chagos Archipelago * (Silva et al., 1996), Maldives (Silva et al., 1996; this study), Nicobar Islands (Silva et al., 1996), Seychelles * (Silva et al., 1996). South-west Asia: India (Silva et al., 1996; Sahoo et al., 2001; Gupta 2012; Rao \& Gupta, 2015). Asia: China (Tseng, 1984; Liu, 2008), Japan (Okamura 1936; Segawa 1981, Yoshida et al., 1990; Yoshida 1998; Yoshida et al., 2015), South China Sea (Phang et al., 2016), Taiwan (Shao, 2003-2014). South-east Asia: Indonesia (Verheij \& Prud'homme van Reine, 1993; Atmadja \& Prud'homme van Reine, 2014), Philippines (Silva et al., 987; Ang et al., 2014), Vietnam (Tien, 2007; Nguyen et al., 2013). Australia and New Zealand: Lord Howe Island (Lewis, 1987), Papua New Guinea (Coppejans et al., 2001), Queensland (Lewis, 1987; Phillips, 1997; Phillips, 2002; Bostock \& Holland, 2010). Pacific Islands: American Samoa (Skelton et al., 2004), Central Polynesia (Tsuda \& Walsh, 2013), Federated States of Micronesia (Lobban \& Tsuda, 2003; Tsuda 2006), Fiji (N'Yeurt et al., 1996; South \& Skelton, 2003; Littler \& Littler 2003; this study), Guam (Lobban \& Tsuda, 2003; Lam \& Zechman, 2006), Mariana Islands (Tsuda, 2003), Marshall Islands (Taylor, 1950), New Caledonia (Payri, 2007; this study), Republic of Palau (Ohba et al., 2007), Solomon Islands (Womersley \& Bailey, 1970; this study), Vanuatu (this study).

N.B.: “*” indicates localities which we suspect may be erroneous records resulting from misleading species identification (referring to T. gardineri rather than T. expeditionis) and should be confirmed with DNA sequencing or detailed anatomical analyses.

Tydemania gardineri A. Gepp \& E. Gepp, 1911. The Codiaceae of the Siboga Expedition including a monograph of Flabellarieae and Udoteae Siboga-Expeditie Monographie LXII: 67-68, 141, pl. XVIII: fig. 155 
Neotype: L.3958458 from Seychelles, Amirante Islands, St. Joseph Atoll [digitized specimen available from L].

We have been unable to locate any of the specimens from the Gepp \& Gepp collection and assume that their syntype collection of $T$. gardineri is lost. Following art. 9.8 of the CIN, we have selected the specimen above because it is from Amirante Islands (Seychelles), one of the syntype localities of $T$. gardineri.

Syntype localities: Chagos Archipelago and Amirante Islands (Gepp \& Gepp, 1911)

Morpho-anatomical description (adapted from the original description of Gepp \& Gepp (1911) and new observations made here):

Thallus calcified, laxly caespitose, greenish-gray, lacking glomeruli and composed of flabella only. Creeping moniliform main axis, $250-570 \mu \mathrm{m}$ in diameter, with sparse cylindrical branches bearing rhizoids below and branches with flabella above. Flabella are borne from long and moniliform stalks with a beaded necklace-like aspect, that are highly dichotomously divided and arise from the main axis singly or in pairs. Stalks are densely arranged and superimposed at the basis of the flabella. Flabella are small, numerous, monostromatic, and composed of aligned siphons dichotomously branched and tapering from 160-340 $\mu \mathrm{m}$ diameter at the base to 30- $60 \mu \mathrm{m}$ diameter at the apices. Constrictions above dichotomies are symmetric with a cell-wall thickening. Growth is horizontal.

\section{Distribution: Western Indian Ocean: Chagos archipelago and Amirante Islands (Gepp \&} Gepp, 1911); northern Madagascar (this study), Mayotte (this study), Banc du Geyser (this 
403 study), Tanzania (this study), Seychelles, Amirante Islands (Coppejans et al., 2001); Asia:

404 Taiwan * (Shao 2003-2004).

405 N.B.: the locality indicated with "*” is suspected to be an erroneous record based on a 406 misidentification of T. expeditionis specimens. 


\section{AKNOWLEDGEMENTS}

408

409

410

411

412

413

414

415

416

417

418

419

420

421

422

423

424

This work was mainly supported by LabEx Corail grant.

Samples were collected during several scientific campaigns and by various collectors who we could like to acknowledge here : Madang, 2012 : http://dx.doi.org/10.17600/12100070 ; New

Caledonia, 2012 : http://dx.doi.org/10.17600/12100060 ; 2017 : N/O Alis PostBlanco1 ;

Kavieng, 2014 : http://dx.doi.org/10.17600/14004400 ; Madagascar, 2016 : MAD

http://dx.doi.org/10.17600/16004700 ; Fiji, 2007 : BSM-Fidji, 10.17600/7100030 ; Vanuatu, 2006 : Santo, http://dx.doi.org/10.17600/6100100; Solomon Islands, 2004: BSM-Salomon, 2004; Mayotte 2016: SIREME. Sample collection in Bunaken and DNA analyses were made possible thanks to the INDESO project, under the research permit 133/SIP/FRP/SM/V/2015 and 918/BLITBANKKP/II/2016 issued by the Indonesian government and under a material transfer agreement between BALITBANG KP (now BRSDM KP, Ministry of Maritime Affairs and Fisheries) and the IRD. The authors would like to thank Thierry Mulochau and Lionel Bigot (Epicure project: TAAF, Ifremer and CUFR Mayotte) for samples collected from the Banc du Geyser.

HV thanks Sofie D'Hondt, Joana Costa and Chiela Cremen for their molecular work on the Bryopsidales. Part of the funding for this study was provided by the Australian Biological Resources Study (project RFL213-08 to HV). 
Table 1: list of molecular markers and corresponding primers

427 Table 2: List of vouchers, Bold sample IDs and Genbank accession numbers

428 Table 3: Morphological observations

429 Figure 1: Maximum clade credibility tree obtained from a Beast analysis of the tufA collapsed

430 dataset. The number of identical haplotypes is indicated between brackets. The origin of each

431 sample is indicated by colored circles and correspond to the map on the right. Results of the

432 ABGD and PTP species delimitation methods are shown and the presence of flabella (F) and

433 glomeruli $(\mathrm{G})$ is indicated.

434

435 Data 1: Overview of the ABGD and PTP species delimitation results for $r b c \mathrm{~L}$

Data 2: Overview of the species ABGD and PTP delimitation results for $18 \mathrm{~S}$ rDNA

437 Data 3: List of specimens studied through molecular and morphological approaches for $T$. expeditionis and T. gardineri 


\section{AUTHORS CONTRIBUTIONS}

440 L. Lagourgue acquired and analyzed most molecular and morphological data, drafted and

441 edited the manuscript; H. Verbruggen collected samples from the Red Sea and Tanzania,

442 produced molecular data for these localities and contributed to writing and editing the

443 manuscript; E. Ampou collected samples from Indonesia and contributed to editing the

444 manuscript; C. Payri collected samples from various localities, and contributed to editing the

445 manuscript. 
447 Ang, P.O, Jr., Sin Man Leung \& Mei Mei Choi (2014). A verification of reports of marine algal species 448 from the Philippines. Philippine Journal of Science, Special Issue 142

449

450

451

452

453

454

455

456

457

458

459

460

461

462

463

464

465

466

467

468

469

470

471

472

473

474

475

476

477

478

479

480

481

482

483

484

485

486

Atmadja, W.S. \& Prud'homme van Reine, W.F. (2014). Checklist of the seaweed species biodiversity of Indonesia with their distribution and classification: green algae (Chlorophyta) and brown algae (Phaeophyceae, Ochrophyta). pp. [2], i-v, 1-59. Leiden \& Indonesia: Naturalis Biodiversity Centre, Indonesian Institute of Sciences (LIPI)

Bostock, P.D. \& Holland, A.E. (2010). Census of the Queensland Flora. pp. 1-320. Brisbane:

Queensland Herbarium Biodiversity and Ecosystem Sciences, Department of Environment and Resource Management.

Coppejans, E., De Clerck, O. \& Leliaert, F. (2001). Marine brown algae (Phaeophyta) from the north coast of Papua New Guinea, with a description of Dictyota magneana sp.nov. Cryptogamie, Algologie, 22:15-40.

Coppejans, E., Leliaert, F. \& De Clerck, O. (2000). Annotated list of new records of marine macroalgae for Kenya and Tanzania, since Isaac's and Jaasund's publications. Biologisch Jaarbuch Dodonaea 67: 31-93, 1 map, 28 figs.

Doyle, J.J. \& Doyle, J.L. (1987). A Rapid DNA Isolation Procedure for Small Quantities of Fresh Leaf Tissue. Phytochemical Bulletin 19, 11-15

Drummond, A.J., Ho, S.Y.W., Phillips, M.J. \& Rambaut, A. (2006). Relaxed Phylogenetics and Dating with Confidence. PLoS Biology 4(5): e88. DOI: 10.1371/journal.pbio.0040088

Edgar, R.C. (2004). MUSCLE: multiple sequence alignment with high accuracy and high throughput. Nucleic Acids Research. 32:1792-7.

Farghaly, M. (1980). Algues Benthiques de la Mer Rouge et du bassin occidental de l'océan Indien. Université des sciences et techniques du Languedoc, Montpellier, 274 pp.

Gepp, A. \& Gepp, E.S. (1911). The codiaceae of the Siboga Expedition, including a monograph of Flabellarieae and Udoteaceae. Siboga-Expeditie. 62:1-150.

Gilmartin, M. (1966). Ecology and morphology of Tydemania expeditions, a tropical deep-water siphonous green alga. Journal of Phycology. 2:100-5.

Guiry, M.D. \& Guiry, G.M. (2019). AlgaeBase. World-wide electronic publication, National University of Ireland, Galway. http://www.algaebase.org

Gupta, R.K. (2012). Algae of India Volume 2. A checklist of Chlorophyceae, Xanthophyceae. Chrysophyceae and Euglenophyceae. pp. [i]-iii, [1]-428, 8 pls. Salt Lake, Kolkata: Botanical Survey of India, Ministry of Environment \& Forests.

Handeler, K., Wagele, H., Wahrmund, U., Rudinger, M. \& Knoop, V. (2010). Slugs' last meals: Molecular identification of sequestered chloroplasts from different algal origins in Sacoglossa (Opisthobranchia, Gastropoda). Molecular Ecology Resources. 10:968-78.

Kearse, M., Moir, R., Wilson, A., Stones-Havas, S., Cheung, M., Sturrock, S., Buxton, S., Cooper, A., Markowitz, S., Duran, C., Thierer, T., Ashton, B., Meintjes, P. \& Drummond, A. (2012). Geneious Basic: An integrated and extendable desktop software platform for the organization and analysis of sequence data. Bioinformatics. 28:1647-9.

Kooistra, W.H.C.F. (2002). Molecular phylogenies of Udoteaceae (Bryopsidales, Chlorophyta) reveal 
nonmonophyly for Udotea, Penicillus and Chlorodesmis. Phycologia. 41:453-62.

Lagourgue, L., Puillandre, N. \& Payri, C.E. (2018). Exploring the Udoteaceae diversity (Bryopsidales, Chlorophyta) in the Caribbean region based on molecular and morphological data. Molecular Phylogenetics and Evolution 127: 758-769.

Lam, D.W. \& Zechman, F.W. (2006). Phylogenetic analyses of the Bryopsidales (Ulvophyceae, Chlorophyta) based on Rubisco large subunit gene sequences. Journal of Phycology. 42:669-78.

Lanfear, R., Calcott, B., Ho, S.Y.W. \& Guindon, S. (2012). PartitionFinder: Combined Selection of Partitioning Schemes and Substitution Models for Phylogenetic Analyses. Molecular Biology and Evolution. 29:1695-701.

Lewis, J.A. (1987). Checklist and bibliography of benthic marine macroalgae recorded from northern Australia III. Chlorophyta. pp. 1- 56.: Department of Defense. Defense Science and Technology Organisation. Materials Research Laboratories, Melbourne, Victoria, Report MRL-R-1063

Littler, D.S. \& Littler, M.M. (2003). South Pacific Reef Plants. A diver's guide to the plant life of the South Pacific Coral Reefs. pp. 1-331. Washington, DC: OffShore Graphics, Inc.

Liu, R.Y. (Ed.) (2008). Checklist of biota of Chinese seas. pp. 1-1267. Beijing: Science Press, Academia Sinica

Lobban, C.S. \& Tsuda, R.T. (2003). Revised checklist of benthic marine macroalgae and seagrasses of Guam and Micronesia. Micronesica 35/36: 54-99

Marconi, M., Giordano, M. \& Raven, J.A. (2011). Impact of taxonomy, geography, and depth on delta13C and delta15N variation in a large collection of macroalgae. Journal of Phycology 47(5): 1023-1035

Meinesz, A. (1981). Sur le genre Tydemania (Udotéacée, Caulerpale) et sa présence en Mer Rouge. Cryptogamie, Algologie. 2:57-66.

Miller, M.A., Pfeiffer, W. \& Schwartz, T. (2010). Creating the CIPRES Science Gateway for inference of large phylogenetic trees. In: Gateway Computing Environments Workshop (GCE). IEEE, pp. 1-8.

N'Yeurt, A.D.R., South, G.R. \& Keats, D.W. (1996). A revised checklist of the benthic marine algae of the Fiji Islands, South Pacific (including the island of Rotuma). Micronesica. 29:49-98.

Nasr, A.H. (1939). Algae. Publications of the Marine Biological Station, Ghardaqa 1: 47-76, 17 figs, 1 plate

Nguyen, T.V., Le, N,H., Lin, S.-M., Steen, F. \& De Clerck, O. (2013). Checklist of the marine macroalgae of Vietnam. Botanica Marina 56(3): 207-227

Ohba, H., Victor, S., Golbuu, Y \& Yukihara, H. (2007). Tropical marine plants of Palau. pp. [1]-153, Numerous colour photographs; 8 figs. Koror: Palau International Coral Reef Center; Japan International Cooperation Agency.

Okamura, K. (1936). Nippon kaisô shi [Descriptions of Japanese algae]. pp. [4], [1]-964, [1]-11, frontispiece portrait, 1-427 figs. Tokyo: Uchida Rokakuho.

Payri, C.E. (2007). Revised checklist of marine algae (Chlorophyta, Rhodophyta and Ochrophyta) and seagrasses (Marine Angiosperma) of New Caledonia. In: Compendium of marine species from New Caledonia. Documents Scientifique et Techniques. II7. Sciences de la Mer. Ed. 2. (Payri, C.E. \& Richer de Forges, B. Eds), pp. 95-112. Nouvelle-Calédonie: Centre IRD de Nouméa

Phang, S.-M., Yeong, H.-Y., Ganzon-Fortes, E.T., Lewmanomont, K., Prathep, A., Hau, L.N., Gerung, G.S, \& Tan, K.S. (2016). Marine algae of the South China Sea bordered by Indonesia, Malaysia, 
Phillips, J.A. (1997). Algae. In: Queensland Plants: Names and Distribution. (Henderson, R.J.F. Eds), pp. 223-240. Indooroopilly, Queensland: Queensland Herbarium, Department of Environment.

Phillips, J.A. (2002). Algae. In: Names and distribution of Queensland plants, algae and lichens.

Puillandre, N., Lambert, A., Brouillet, S. \& Achaz, G. (2012). ABGD , Automatic Barcode Gap Discovery for primary species delimitation. Molecular Biology and Evolution. 1864-77.

Rambaut, A. \& Drummond, A. (2007). Tracer version 1.5.

Rao, P.S.N. \& Gupta, R.K. (2015). Algae of India Volume 3. A checklist of Indian marine algae (excluding diatoms \& dinoflagellates). pp. [i]-xviii, [1]-93, 11 pls. Salt Lake, Kolkata: Botanical Survey of India Ministry of Environment, Forests \& Climate Change Government of India

Ronquist, F. \& Huelsenbeck, J.P. (2003). MrBayes 3: Bayesian phylogenetic inference under mixed models. Bioinformatics (Oxford, England). 19:1572-4.

Sahoo, D., Nivedita \& Debasish (2001). Seaweeds of Indian coast. pp. xxi + 283. New Delhi: A.P.H.

\section{Publishing}

Segawa, S. (1981). Genshoku Nihon kaiso zukan. Colored illustrations of the seaweeds of Japan. Fourth printing. pp. [i]-xviii, 1-195, pls 1-72. Osaka: Hoikusha Publishing Co. Ltd

Shao, K.T (2003-2014). TaiBNET (Catalogue of Life in Taiwan). http://taibnet.sinica.edu.tw. Taiwan

Silva, P.C., Menez, E.G. \& Moe, R.L. (1987). Catalog of the benthic marine algae of the Philippines. Smithsonian Institution Press, Washington, D.C. 1-179 pp.

Silva, P.C., Basson, P.W. \& Moe, R.L. (1996). Catalogue of the benthic marine algae of the Indian Ocean. University of California Publications in Botany 79: 1-1259

Skelton, P.A. \& South, G.R. (2004). New records and notes on marine benthic algae of American Samoa - Chlorophyta \& Phaeophyta. Cryptogamie Algologie 25: 291-312

South, G.R. \& Skelton, P.A. (2003). Catalogue of the marine benthic macroalgae of the Fiji Islands, South Pacific. Australian Systematic Botany 16: 699-758

Srinivasan, K.S. (1954). On a rare and little known alga (Tydemania expeditionis Weber-van Bosse) new to Nancowry. Phytomorphology 4: 247-255.

Stamatakis, A. (2014). RAxML version 8: a tool for phylogenetic analysis and post-analysis of large phylogenies. Bioinformatics. 30:1312-3.

Stamatakis, A., Hoover, P., Rougemont, J. \& Renner, S. (2008). A Rapid Bootstrap Algorithm for the RAxML Web Servers. Systematic Biology. 57:758-71.

562 Taylor, W.R. (1950). Plants of Bikini and other northern Marshall Islands. pp. [i]-xv, [1]- 227, 79 pls. 563 Ann Arbor: University of Michigan Press

Thiers, B. (2016). Index Herbariorum: A Global Directory of Public Herbaria and Associated Staff. New York Botanical Garden's Virtual Herbarium. http://sweetgum.nybg.org/science/ih/

Tien, N.V. (2007). Thuc Vât Chí Viêt Nam. Flora of Vietnam. Volume 10: Nganh Rong Luc - 
570 Tsuda, R.T. (2003). Checklist and bibliography of the marine benthic algae from the Mariana Islands

571 (Guam and CNMI). Technical Report. University of Guam Marine Laboratory 107: i-v, 1-49

572 Tsuda, R.T. (2006). Checklist and bibliography of the marine benthic algae within Chuuk, Pohnpei, and

573 Kosrae States, Federated States of Micronesia. pp. 1-43. Honolulu: Bishop Museum Press 1525

574 Bernice Street, Honolulu, Hawai

575 Tsuda, R.T. \& Walsh, S.K. (2013). Bibliographic checklist of the marine benthic algae of Central

576 Polynesia in the Pacific Ocean (excluding Hawai'i and French Polynesia). Micronesica. 2013-02: 1-91

577 Verbruggen, H., Ashworth, M., LoDuca, S.T., Vlaeminck, C., Cocquyt, E., Sauvage, T., Zechman, F.W.,

578 Littler, D.S., Littler, M.M., Leliaert, F. \& De Clerck, O. (2009). A multi-locus time-calibrated phylogeny

579 of the siphonous green algae. Molecular Phylogenetics and Evolution. 50:642-53.

580 Verheij, E. \& Prud'homme van Reine, W.F. (1993). Seaweeds of the Spermonde Archipelago, SW

581 Sulawesi, Indonesia. Blumea 37: 385-510, 6 figs, 1 table, 19 plates

582 Weber-van Bosse, A. (1901). Etudes sur les algues de l'archipel malaisien. Annales du Jardin

583 Botanique de Buitenzorg. 17: 126-141, pls XVII-XIX..

584 Womersley, H.B.S. \& Bailey, A. (1970). Marine algae of the Solomon Islands. Philosophical

585 Transactions of the Royal Society, London.Biological Series B. 259:257-352.

586 Yoshida, T. (1998). Marine algae of Japan. pp. [1-2], 1-25, 1-1222. Tokyo: Uchida Rokakuho Publishing 587 Co., Ltd.

588 Yoshida, T., Nakajima, Y. \& Nakata, Y. (1990). Check-list of marine algae of Japan (revised in 1990).

589 Japanese Journal of Phycology 38: 269-320

590 Yoshida, T., Suzuki, M. \& Yoshinaga, K (2015). Checklist of marine algae of Japan (Revised in 2015).

591 Japanese Journal of Phycology 63: 129-189

592 Zhang, J., Kapli, P., Pavlidis, P. \& Stamatakis, A. (2013). A general species delimitation method with

593 applications to phylogenetic placements. Bioinformatics. 29:2869-76. 
Table 1: Morpho-anatomical characters and geographical distribution of Tydemania from the descriptions of Gepp \&Gepp (1911). Values (average \pm standart deviation)

\begin{tabular}{|c|c|c|}
\hline $\begin{array}{l}\text { Morpho- } \\
\text { anatomical } \\
\text { characters }\end{array}$ & Tydemania expeditionis & Tydemania gardineri \\
\hline Habit & $\begin{array}{l}\text { Upright structures formed by a } \\
\text { succession of glomeruli and/or } \\
\text { flabella }\end{array}$ & $\begin{array}{l}\text { Caespitose patch of flabella } \\
\text { arising from a creeping main } \\
\text { axis }\end{array}$ \\
\hline Glomeruli & $\begin{array}{l}\text { Predominant when present/ } \\
\text { Lacking in strict flabella form }\end{array}$ & Always absent \\
\hline Flabella & $\begin{array}{l}\text { Sometimes absent (strict } \\
\text { glomeruli form) }\end{array}$ & Always present \\
\hline $\begin{array}{l}\text { Diameter of the } \\
\text { main axis }\end{array}$ & $\begin{array}{c}360-780 \mu \mathrm{m}(518 \pm 100) \\
(\mathbf{4 5 0 - 5 0 0} \boldsymbol{\mu m})\end{array}$ & $\begin{array}{c}285-570 \mu \mathrm{m}(426 \pm 94) \\
(\mathbf{2 5 0}-\mathbf{4 0 0} \boldsymbol{\mu m})\end{array}$ \\
\hline $\begin{array}{c}\text { Diameter of flabella } \\
\text { siphons at apices }\end{array}$ & $\begin{array}{c}\text { 60-130 } \mu \mathrm{m}(79 \pm 13) \\
(\text { Min. } 63 \mu \mathrm{m})\end{array}$ & $\begin{array}{c}30-60 \mu \mathrm{m}(44.5 \pm 7) \\
(\mathbf{5 0 - 4 0} \boldsymbol{\mu m})\end{array}$ \\
\hline $\begin{array}{c}\text { Flabella shape and } \\
\text { number }\end{array}$ & $\begin{array}{l}\text { Flabella generally big and in small } \\
\text { number ( } 1 \text { to } 4) \text {, arising one by } \\
\text { one or in pairs, and forming loose } \\
\text { groups }\end{array}$ & $\begin{array}{l}\text { Flabella generally small but } \\
\text { numerous (several dozens), } \\
\text { assembled in dense groups }\end{array}$ \\
\hline Stalk & $\begin{array}{l}\text { Short, stocky and fewly divided } \\
\text { dichotomously (1-2) }\end{array}$ & $\begin{array}{l}\text { Long, highly dichotomously } \\
\text { divided, monoliform with }\end{array}$ \\
\hline
\end{tabular}




\begin{tabular}{|c|l|l|}
\hline & & $\begin{array}{l}\text { strong constrictions (beaded } \\
\text { siphons), crowded and } \\
\text { superimposed at the basis of } \\
\text { the flabella }\end{array}$ \\
\hline Stalk aspect & Monoliform to septate & Monoliform \\
\hline main axis & $\begin{array}{l}\text { In whorls, arising in groups of two } \\
\text { or four, on the same section of the } \\
\text { main axis. }\end{array}$ & Simple, arising from the main \\
axis
\end{tabular}


601

602

603

604

605

606

607

608

609

610

611

612

613

614

615

616

617

618

619

620

621

622

623

Figure 1: Diagram showing the different morphological structures of Tydemania: specimen with both glomeruli and flabella (left), and with flabella only (right).

Figures 2-14: Tydemania expeditionis. Fig. 2: In situ habit of the thalli with flabella and glomeruli; Fig. 3: In situ habit of the thalli with glomeruli only; Fig. 4: In situ habit of the thalli with flabella only; Fig. 5: Succession of flabella and glomeruli arising from the main axis; Fig. 6: Monoliform main axis near glomeruli and flabella; Fig. 7: Siphons branching dichotomously; Fig. 8: Anisomorphic dichotomy; Fig. 9: Short and monoliform stalks with a few dichotomous divisions (flabella form) ; Fig. 10 : Short and monoliform stalks with few dichotomous divisions (glomeruli form); Fig. 11: Verticillate stalks at the basis of a flabella; Fig. 12: Verticillate stalks at the basis of a glomeruli; Fig. 13: Apex of the main axis protruding at the top of a flabella; Fig. 14: Apex of main axis protruding at the top of a glomeruli. Scale bars: Fig. 2: 0.8 cm; Fig. 3: $3.2 \mathrm{~cm}$; Fig. 4: 2 cm; Fig. 5: 3.5 mm; Fig. 6: $600 \mu \mathrm{m}$; Fig. 7: $320 \mu \mathrm{m}$; Fig. 8: $160 \mu \mathrm{m}$; Fig. 9: $760 \mu \mathrm{m}$; Fig. 10: $820 \mu \mathrm{m}$; Fig. 11: $475 \mu \mathrm{m}$; Fig. 12: $800 \mu \mathrm{m}$; Fig. 13: $875 \mu \mathrm{m}$; Fig. 14: $500 \mu \mathrm{m}$.

Figures 15-24: Tydemania gardineri: Fig. 15 and 16: In situ habit of a thalli with flabella only; Fig. 17-19: Groups of flabella supported by long, monoliform and highly dichotomously divided stalks; Fig. 20-22: Zoom on the beaded and crowded aspect of stalks at the basis of flabella; Fig. 23: Monoliform and strongly constricted stalks; Fig. 24: Basis of flabella showing the dichotomous branching. Scale bars: Fig. 15: 5.6 mm; Fig. 16: 7 mm ; Fig. 17: 11 mm; Fig. 18: 5.8 mm; Fig. 19: 5.4mm; Fig. 20: $500 \mu \mathrm{m}$; Fig. 21: $625 \mu \mathrm{m}$; Fig. 22: $720 \mu \mathrm{m}$; Fig. 23: $350 \mu \mathrm{m}$; Fig. 24: $250 \mu \mathrm{m}$. 
624 Figure 25: From left to right: (1) Maximum likelihood tree reconstruction from the

625 concatenated matrix (tufA, $r b c \mathrm{~L}$ and $18 \mathrm{~S}$ rDNA). Circles at each node represent ML bootstrap

626 values (left) and posterior probabilities (right). Black circles indicate high support (bs> 90 and

627 PP >95), grey circles indicate low support (bs<90 and PP <95), and white circles indicate

628 incongruence between maximum likelihood and Bayesian trees. (2) Habit information for

629 each specimen: presence of flabella (F) or glomeruli (G). (3) Grouping of sequences per

630 marker according to the results of the species delimitation analyses (stripes indicate missing

631 sequences). (4) Global geographical distribution. (5) Drawings showing the external habits

632 observed for specimens in each of the two main clades. (6) Map showing the distribution of

633 specimens from the two main clades 